\title{
Transplant antibodies vie for attention
}

The imminent approval of two products in the United States and in Europe could provide a head-to-head test of two distinct monoclonal antibody technologies. Zenapax from Hoffmann-La Roche (Basel, Switzerland) and Simulect from Novartis (Basel, Switzerland), are both targeted at the cell-surface receptor of the cytokine interleukin-2, and both aim to prevent the rejection of transplanted kidneys. Zenapax is the first "humanized" antibody on the market, launched in mid-December 1997-only its complementarity determining regions are of mouse origin. In contrast, Simulect, which is a few months behind in the development cycle, is a chimeric antibody-in essence a human IgG molecule with a variable region of a mouse antibody spliced on.

Both chimerization or humanization aim to reduce the immunogenicity of the antibody, minimize the production of neutralizing antibodies, and thereby to confer a longer half-life and greater clinical effect. Peter Amlot, the immunologist at the Royal Free Hospital (London, UK), who isolated the mouse antibody on which the chimeric Simulect is based concedes that "humanized versions could in theory be the cleanest antibodies." However, he says that "there is very little evidence that this gives you any advantage." Indeed, although humanized antibodies may be less immunogenic, antibody affinity can be reduced during humanization, he says. The phase III trials for Zenapax and Simulect show only that there is little to choose between the products' efficacies.

Roche officials say that Zenapax administered in combination with cyclosporin and corticosteroids (dual immunosuppressive therapy) reduced the incidence of acute rejection by $40 \%$, when azathioprine is added (triple immunosuppressive therapy), a reduction of $37 \%$ is seen. Simulect (The Lancet, October 25, p. 1193) reduced acute rejection $36 \%$ over dual therapy alone. Both sets of results are from six months posttransplantation.

There is not much to choose from between the two products based on immunogenicity either. Novartis reported that there was no antibody response to the product. According to Albrecht Schmitt, leader of the Simulect clinical program at Novartis, "There was very low antigenicity and one object of chimerization, to reduce the antigenicity of the antibody, had been

Sylvia Davidson is a freelance writer working in London. achieved." Roche had reported antiidiotypic antibodies in $15 \%$ of Zenapax patients. But Nicholas Benedict, product manager for Zenapax, noted that this response did not affect efficacy, "There was no correlation between being positive for antiidiotypic antibodies [and] either the pharmacokinetics ... or to the efficacy or safety." He also pointed out that when Roche had conducted its assays under the same, less stringent, incubation condition as Novartis had done, no antibodies were detectable.

There are indications, however, that humanized antibodies are less immunogenic. According to Benedict, Zenapax can be administered for three months after the transplant, thereby providing receptor saturation and protection during the time of greatest risk for acute transplant rejection. In contrast, he says, Simulect is given twice, just once before transplantation and a second time four days later. However, Schmitt argues that the simplicity of the dosing regimen demonstrates, not an disadvantage in immunogencity, but an advantage in affinity of the chimerized antibody: "Because Simulect retains the [high-affinity] mouse variable region, no affinity has been lost from the original in the chimerization." There would be no point in humanizing the antibody," he claims.

Kidney transplantation may not be the best indication in which to compare immunogenicity of treatments. Peter Amlot notes that "the real test of immunogenicity comes when you don't have immunosuppressants." Zenapax has been administered alone for up to 12 months in a clinical study in an eye disease, uveitis, says Benedict, and no problems associated with antiidiotypic responses have been identified. As Larry Korn, CEO of Protein Design (Mountain View, CA), the company which humanized Zenepax and licensed it to Roche, confirms: "There isn't data on the chimeric antibody over long-term dosing. There is data for the humanized antibody."

Most companies are now developing humanized antibodies because, says Julia Greenstein, chief scientific officer at BioTransplant (Charlestown, MA), there is "less risk involved because humanization is now as routine as chimerization," and as it can be done so routinely one might as well do it. BioTransplant put a rodent antibody (BTI 322), licensed from the Catholic University of Louvain (Belgium) for the prevention of acute rejection of organ transplants, into phase I/II trials in February 1996. But, in collaboration with MedImmune (Gaithersburg, MD), it moved to a humanized version (MEDI 507) in May 1997. The reduction of affinity argument is also no longer valid, noted Korn, "with an anti-CD33 humanized antibody ... we actually increased binding affinity 5-7-fold. We routinely maintain binding affinity."

The humanization versus chimerization debate may become purely academic, as both technologies are, according to David Chiswell, CEO of Cambridge Antibody Technology (UK), already "obsolete," as $t$ is now "quicker to get a human antibody than to start with a mouse antibody and humanize it." he says. Whereas humanization might take two to three months on top of the time taken to isolate the original rodent antibody, the production of "human" antibodies takes only days, he says. There is still the problem of determining which human antibody will be suitable for the clinic. An antitumor necrosis factor human antibody produced by CAT is already in clinical trials for the treatment of rheumatoid arthritis with BASF (Ludwigshafen, Germany).

Sylvia Davidson

\section{TIME IS MONEY SAVE BOTH}

\section{DNA SEQUENCING $\$ 1.25$ per base pair}

\section{PRIMERS $\$ 1.00$ per base}

We Also Offer:

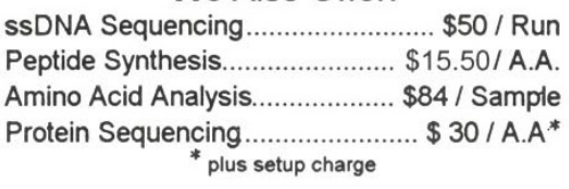

For More Information Call Us Today

800-343-8998

http://www.ssr4dna.com
Southwest Scientific Resources Inc.
*DEPENDABLE * ACCURATE* *AFFORDABLE*

